\title{
RELASI GENDER DALAM PENGAMBILAN KEBIJAKAN STRATEGIS PARTAI PADA PARTAI ISLAM
}

\author{
Nila Sastrawati \\ Dosen Fakultas Syariah dan Hukum UIN Alauddin Makassar
}

\begin{abstract}
Abstrak
Sistem internal partai tidak terlepas dari relasi yang terbangun antara identitas perempuan dan identitas laki-laki. Bryan menjelaskan bahwa dalam teori sosialisasi, perbedaan laki-laki dan perempuan dibentuk oleh variasi budaya, dan dalam analisis conversational menunjukkan perbedaan dalam pola gangguan percakapan antara laki-laki dan perempuan yang bermuatan penggunaan kekuatan. Di dalam organisasi dimana laki-laki dan perempuan memperjuangkan sebuah kekuasaan, komunikasi yang terjalin tetap mengandung muatan kekuasaan laki-laki. Dalam konteks ini, postmodernism menempatkan lakilaki dan perempuan dengan "ide identitas laki-laki yang plural" dan ide identitas perempuan yang plural", bukan pada tataran "kesamaan laki-laki dan perempuan".
\end{abstract}

Kata Kunci:

Relasi gender

\section{Pendahuluan}

7 ra reformasi telah memberikan harapan baru bagi gerakan transformasi demokrasi untuk mewujudkan kehidupan demokratis sebagaimana diperjuangkan banyak kalangan. Banyak agenda - agenda penting khususnya yang berkaitan dengan keadilan dan kesetaraan yang sebelumnya terabaikan saat ini kembali menjadi agenda penting untuk diperjuangkan.

Persoalan mendasar dari beberapa agenda tersebut adalah muatan-muatan yang mengarah pada pentingnya pelibatan perempuan pada berbagai aspek kehidupan sosial dan politik, dimana kondisi tersebut cenderung berbanding terbalik dengan beragam hambatan dan tantangan yang harus dihadapi kaum perempuan salah satunya bermuara pada kebijakan - kebijakan yang tidak berbasis gender. Faktor budaya, sistem sosial, sistem politik, masalah kemiskinan merupakan 
masalah-masalah yang menjadi penghalang perempuan khususnya untuk berkiprah pada wilayah publik. Realitas ini menunjukkan bahwa perempuan harus memiliki usaha strategis untuk keluar dari hambatan dan tantangan tersebut, sebab faktor budaya, politik, ekonomi merupakan agenda umum yang pada kenyataannya belum tertangani dengan baik sampai saat ini.

Banyak yang menyepakati gerakan perempuan untuk memulihkan hak - hak politiknya sangat berkaitan erat dengan transformasi sosial yang identik dengan transformasi demokrasi. Alasannya, tujuan gerakan perempuan adalah menciptakan hubungan antar sesame manusia secara fundamental baru, lebih adil, dan saling menghargai. (Jurnal Perempuan Nomor 45;83)

Sebuah masyarakat dapat dikatakan demokratis jika dalam kehidupannya menghargai hak asasi manusia secara adil dan setara. Salah satu bentuk konkrit dari penghargaan tersebut adalah adanya jaminan partisipasi politik semua masyarakat termasuk kalangan perempuan. Dryzek (Rupiarsih,2009;3) memandang bahwa persoalan perempuan harus dipandang sebagai demokrasi inklusif, yaitu kehendak apapun, diminta atau tidak diminta oleh siapapun, oleh sekelompok orang yang tidak beruntung entah alasan politik, sosial, ekonomi, gender, dan lain-lain, Negara wajib memenuhi atau memikirkannya.

Menempatkan perempuan sebagai bagian dari warga negara Indonesia sebagaimana halnya dengan laki-laki bukan suatu hal yang mudah. Berbagai tantangan dan hambatan harus dilalui untuk menghasilkan regulasi politik yang berpihak pada eksistensi perempuan dalam ranah politik. Siti Musdah Mulia $(2005 ; 1)$ mengemukakan bahwa selama ini, politik dan perilaku politik dipandang sebagai aktifitas maskulin. Perilaku politik yang dimaksud di sini mencakup kemandirian, kebebasan berpendapat, dan tindakan agresif. Ketiga karakteristik tersebut tidak pernah dianggap ideal dalam diri perempuan. Dengan kata lain karakteristik tersebut adalah milik laki-laki.

Beberapa hasil penelitian menunjukkan bahwa salah satu kendala berkaitan erat dengan eksistensi perempuan dan politik dalam konteks penafsiran ajaran agama yang berbeda khususnya dikalangan umat Islam sendiri. Beberapa ajaran agama tertentu dipandang menghalangi ruang gerak perempuan disektor publik. Misalnya "perempuan tidak boleh bekerja" atau "perempuan tidak boleh jadi pemimpin".

Salah satu respon keras yang muncul dari Kongres Umat Islam Indonesia (KUII) tahun 1998 yang mengeluarkan fatwa "Presiden Indonesia haruslah seorang pria muslim". Fatwa ini dipahami masyarakat bahwa "Presiden Indonesia haruslah seorang pria" berarti "Presiden Perempuan itu Haram". Demikian juga komentar Amin Rais dan elit agama lainnya bahwa perempuan boleh menjadi pemimpin selama tidak ada laki-laki yang becus menempati posisi tersebut.

Realitas politik Indonesia sangat sulit untuk memisahkan isu politik dengan isu agama. Arbi Sanit $(2002 ; 24)$ memandang bahwa partai politik yang berbasis keagamaan masih merupakan faktor signifikan untuk melihat peta politik di Indonesia.Hal ini disebabkan karena keterwakilan politik sangat ditentukan oleh keterkaitan antara partai politik dengan massa yang diwakilinya. Sejalan dengan ketergantungan partai dan dukungan masyarakat untuk memperoleh kemenangan 
di dalam Pemilu pertama di Indonesia, maka pengaruh ikatan-ikatan primordial seperti suku, agama, dan kedaerahan semakin Nampak mempengaruhi pengorganisasi partai-partai politik.

Dua tema penting dalam kajian ini yakni "perempuan" dan "agama" merupakan kajian yang hingga saat ini belum berkesudahan. Siti Hariti melihat marginalisasi perempuan menurut pandangan aliran feminism Islam (110:2009) yang tergabung dalam Teori Feminisme Kontemporer, yang terjadi baik dalam lingkungan keluarga maupun lingkungan diakibatkan oleh adanya kesalahan interpretasi pada teks-teks agama Islam. Akibatnya, kaum perempuan maupun lakilaki mengubah kondisi tersebut dengan mengacu pada hukum Islam sebagai pijakan. Feminisme Islam berkeyakinan bahwa memperjuangkan feminism juga berarti memperjuangkan nilai-nilai Islam, karena di dalam ajaran Islam terdapat konsep kesetaraan jender dan penghormatan terhadap hak - hak asasi manusia.

Sebagaimana telah dikemukakan bahwa pandangan beberapa elit agama yang cenderung tidak memberikan peluang bagi perempuan dalam aktifitas ranah politik, memberikan efek dimana pemahaman - pemahaman keagamaan yang membatasi ruang gerak perempuan termasuk hak - hak politiknya telah diserap masyarakat dan semakin meminggirkan kaum perempuan. Di sisi lain, gerakan transformasi demokrasi terus diupayakan dengan mengusung konsep affirmative action yang bertujuan memberikan peluang kepada perempuan untuk dapat terintegrasi dalam kehidupan publik secara adil. Momentum dalam menilai keseriusan dan menguji komitmen sistem politik, antara lain dapat dicermati dari kesediaan salah satu komponen dari perangkat sistem politik yakni Partai Politik untuk mengakomodir perempuan dalam kepengurusan Partai khususnya pada Partai Islam.Posisi perempuan dalam struktur kepengurusan Partai Politik memegang peranan penting, selain sebagai faktor penentu keterwakilan perempuan dalam parlemen, yang nantinya memperjuangkan isu-isu perempuan.

Berkaitan dengan latar belakang tersebut, maka dianggap penting untuk mengkaji ; Pertama, bagaimana platform tentang isu perempuan pada Partai Islam, kedua, bagaimana eksistensi perempuan Partai Politik Islam khususnya dalam perumusan, pelaksanaan, dan pengawasan kebijakan strategis partai; ketiga, bagaimana

\section{Pembahasan Penelitian}

\section{Perempuan dalam Sistem Multi Partai}

Era reformasi menggambarkan bergulirnya pendirian partai politik hampir dikatakan tidak terbendung. Sepintas tampak sebagai gejala yang menggembirakan, di sisi lain masyarakat semakin bingung dengan keberadaan partai politik yang sedemikian banyak dengan perbedaan yang hampir dapat dikatakan tidak ada, belum lagi mekanisme persaingan antara partai politik yang mengeluarkan cost yangcukup besar. Realitas tersebut memberikan tekanan kepada partai politik untuk menyusun strategi yang tepat serta memperhatikan unsur-unsur penting dalam partai sebagai upaya melanggengkan eksistensi partai,mengingat bahwa perjuangan politik partai sangat ditentukan oleh dukungan semua politisi dan sistem internal 
partai.

Tabel 1 : Partai Politik Peserta Pemilu Tahun 2009

\begin{tabular}{|c|c|}
\hline No Urut & Nama Partai \\
\hline 1 & Partai Hati Nurani Rakyat \\
\hline 2 & Partai Karya Peduli Bangsa \\
\hline 3 & Partai Pengusaha dan Pekerja Nasional \\
\hline 4 & Partai Peduli Rakyat Indonesia \\
\hline 5 & Partai Gerakan Indonesia Indonesia Raya \\
\hline 6 & Partai Barisan Nasional \\
\hline 7 & Partai Keadilan Persatuan Indonesia \\
\hline 8 & Partai Keadilan Sejahtera \\
\hline 9 & Partai Amanat Nasional \\
\hline 10 & Partai Perjuangan Indonesia Baru \\
\hline 11 & Partai Kedaulatan \\
\hline 12 & Partai Persatuan Daerah \\
\hline 13 & Partai Keangkitan Bangsa \\
\hline 14 & Partai Pemuda Indonesia \\
\hline 15 & Partai Nasional Indonesia Marhaenisme \\
\hline 16 & Partai Demokrasi Pembaharuan \\
\hline 17 & Partai Karya Perjuangan \\
\hline 18 & Partai Matahari Bangsa \\
\hline 19 & Partai Penegak Demokrasi Indonesia \\
\hline 20 & Partai Demokrasi Kebangsaan \\
\hline 21 & Partai Republika Nusantara \\
\hline 22 & Partai Pelopor \\
\hline 23 & Partai Golongan Karya \\
\hline 24 & Partai Persatuan Pembangunan \\
\hline 25 & Partai Damai Sejahtera \\
\hline 26 & Partai Nasional Benteng Kerakyatan Indonesia \\
\hline 27 & Partai Bulan Bintang \\
\hline 28 & Partai Demokrasi Indonesia Perjuangan \\
\hline 29 & Partai Bintang Reformasi \\
\hline 30 & Partai Patriot \\
\hline 31 & Partai Demokrat \\
\hline 32 & Partai Kasih Demokrasi Indonesia \\
\hline 33 & Partai Indonesia Sejahtera \\
\hline 34 & Partai Kebangkitan Nasional Ulama \\
\hline 35 & Partai Merdeka \\
\hline 36 & Partai Nahdatul Ummah Indonesia \\
\hline 37 & Partai Sarikat Indonesia \\
\hline 38 & Partai Buruh \\
\hline
\end{tabular}

Sumber: Badan Pusat Statistik Republika Indonesia (file://F:/view.php.htm)

Sistem multi partai yang diterapkan pada era reformasi bukan tanpa konsekuensi. Beberapa pengamat politik bahkan berpendapat bahwa pada era 
reformasi ini partai politik menghadapi krisis khususnya berkaitan dengan citra di hadapan publik. Partai politik dianggap tidak atau belum mampu menjalankan fungsi-fungsi yang dimiliki secara optimal.Bahkan dalam sebuah diskusi politik, partai politik dianggap menuju titik nadir.(lihat, Indra J Piliang dalam Gatra News,08 Mei 2012).

Realitas politik di Indonesia menunjukkan kesamaan partai dengan ideologi pendukung partai belum merupakan jaminan kelanggengan suatu partai. Hal tersebut terbukti dari merosotnya suara partai Islam dalam pemilihan umum tahun 2009 yang lalu. Oleh karena itu, pandangan bahwa ideologi partai bukan jaminan dalam menarik suara masyarakat dapat dimaklumi.Sebagaimana dikemukakan Mallarangeng (2008) bahwa sistem internal partai ikut menentukan eksis tidaknya partai di tengah realitas politik Indonesia. Sistem internal partai terkait erat dengan situasi,kondisi, dan iklim organisasi yang menghadirkan relasi sosial yang positif yang dinampakkan kebebasan berbicara dan berpendapat tanpa adanya pembedaan dari aspek apapun.

Sistem internal partai tidak terlepas dari relasi yang terbangun antara identitas perempuan dan identitas laki-laki. Bryan menjelaskan bahwa dalam teori sosialisasi, perbedaan laki-laki dan perempuan dibentuk oleh variasi budaya, dan dalam analisis conversational menunjukkan perbedaan dalam pola gangguan percakapan antara laki-laki dan perempuan yang bermuatan penggunaan kekuatan. Di dalam organisasi dimana laki-laki dan perempuan memperjuangkan sebuah kekuasaan, komunikasi yang terjalin tetap mengandung muatan kekuasaan laki-laki. Dalam konteks ini, postmodernism menempatkan laki-laki dan perempuan dengan "ide identitas laki-laki yang plural" dan ide identitas perempuan yang plural", bukan pada tataran "kesamaan laki-laki dan perempuan".

Isu kesetaraan gender telah menjadi hal menonjol dalam platform pembangunan, tidak saja di Indonesia, tetapi juga di dunia internasional. Asumsi yang mendasari isu tersebut adalah bahwa masalah perempuan seringkali ditempatkan sebagaimasalah umum, bukan pada masalah identitas perempuan sehingga penangananya tidak secara proporsional karena ketidakterlibatannya dalam pengambilan keputusan. Keterwakilan perempuan dalam segala bentuk kesempatan termasuk dalam parlemen menjadi sebuah hal yang patut diwujudkan, sebab regulasi telahmengatur sebagai bentuk keseriusan pelibatan seluruh elemen masyarakat melalui gerakan Affirmative action yang diwujudkan dalam Undangundang Partai Politik No. 31 tahun 2002 yang mengatur keterlibatan perempuan dalam kepengurusan partai politik dan kuota pencalonan legislatif perempuan sebanyak $30 \%$.

Undang-Undang tersebut ternyata belum menunjukkan angka keberhasilan yang signifi kan karena baru mencapai 18.04\% (101 orang dari 560 orang anggota) keterwakilan perempuan di Dewan Perwakilan Rakyat (DPR). sementara keterwakilan perempuan di Dewan Perwakilan Daerah (DPD) mencapai 26.52\% (35 orang dari 132 orang anggota).Tingkat keberhasilan perempuan yang tidak signifikan untuk berkiprah lebihluas dalam ranah public bukan hanya karena regulai semata, sebab terdapat perempuan tidak memilik cukup kepercayaan diri untuk terlibat dalam politik belum lagi pemilih merasa sanksi akan kemampuan 
perempuan.

\section{Platform tentang Isu Perempuan pada Partai Politik Islam}

Realitas politik di Indonesia masih sangat sulit memisahkan isu agama dari dunia politik. Hal tersebut dapat dicermati ketika pemilihan umum berlangsung dimana jargon-jargon politik sangat bias gender,meskipun regulasi telah mengatur tentang keterlibatan perempuan dalam pesta demokrasi tetatpi perempuan masih terkukung akibat konstruksi sosial yang telah mengakar dalam masyarakat.

Salah satu strategi yang dapat dilakukan partai politik adalah menempatkan perempuan pada level yang sama dengan laki-laki melalui "citra" simbol partai misalnya lambing dan jargon.Partai-partai Islam cenderung hanya menjabarkan identitas partai dalam konteks "maskulinitas". Pemaknaan simbol baik berupa lambang/visual maupun jargon pada dasarnya dapat digunakan partai politik untuk memperoleh dukungan massa baik masyarakat maupun internal partai sendiri. Gambar padi pada Partai Keadilan Sejahtera (PKS) bukan hanya berarti "sejahtera" tetapi juga mengandung relasi gender yang kuat sebab dalam legenda Indonesia Dewi Sri di legendakan sebagai "Dewi Padi". Gambar Bulan dan Bintang merupakan penggambaran relasi yang seimbang dan bentuk visual lainnya. Dalam internal partai, keterlibatan perempuan dalam politik juga sangat ditentukan sejauhamana partai menyikapi isu perempuanmelalui penjabaran program dan platform partai.Syafiq Hasim (2002) menjabarkan platfomperempuan pada lima Partai Politik Islam di Indonesia.

Tabel 2: Isu Perempuan dalam Platfom Partai Islam

\begin{tabular}{|c|c|c|c|}
\hline artai & $\begin{array}{l}\text { Platfom } \\
\text { tentang Isu } \\
\text { Perempuan }\end{array}$ & $\begin{array}{l}\text { Prioritas Program terkait } \\
\text { dengan Perempuan }\end{array}$ & Kritik \\
\hline BB & $\begin{array}{l}\text { Masih konservatif } \\
\text { dalam menghargai } \\
\text { perempuan } \\
\text { meskipun } \\
\text { sudahmengakomoda } \\
\text { si ide-ide modern } \\
\text { tentang } \\
\text { pemberdayaan } \\
\text { perempuan }\end{array}$ & $\begin{array}{l}\text { Membuat persyaratan keterlibatan } \\
\text { perempuan di dunia politik yakni } \\
\text { memiliki kapasitas dan } \\
\text { keterampilan yang memadai, } \\
\text { semangat untuk membela hak-hak } \\
\text { mereka sendiri, memiliki } \\
\text { kredibilitas dikalangan } \\
\text { masyarakat, diakui oleh } \\
\text { masyarakat umum dan memiliki } \\
\text { ide-ide yangpenting dan startegis } \\
\text { bagimasyarakat }\end{array}$ & $\begin{array}{l}\text { Partai ini } \\
\text { seharusnya } \\
\text { lebih melihat } \\
\text { keterbelakanga } \\
\text { n kaum } \\
\text { perempuan di } \\
\text { dunia politik } \\
\text { bukan hanya } \\
\text { karena } \\
\text { kelemahan } \\
\text { posisi } \\
\text { perempuan } \\
\text { dan } \\
\text { ktidakcakapan } \\
\text { perempuan } \\
\text { saja }\end{array}$ \\
\hline PP & $\begin{array}{c}\text { - Lebih melihat } \\
\text { masalah }\end{array}$ & $\begin{array}{l}\text { - } \begin{array}{l}\text { Memperbaiki sistem } \\
\text { pendidikan }\end{array} \\
\end{array}$ & $\begin{array}{l}\text { Partai ini } \\
\text { tidak }\end{array}$ \\
\hline
\end{tabular}




\begin{tabular}{|c|c|c|c|}
\hline & $\begin{array}{l}\text { pendidikan } \\
\text { perempuan } \\
\text { Pemerintah } \\
\text { telahmemberi } \\
\text { kesempatan tetapi } \\
\text { kaum perempuan } \\
\text { tidak } \\
\text { mengaksesnya }\end{array}$ & $\begin{array}{ll}\text { - } & \text { Pendidikanmerupakanalat } \\
\text { meraih kesempatan yang } \\
\text { setara } \\
\text { - } \\
\text { Mengkritik gerakan } \\
\text { perempuan yang hanya } \\
\text { menuntut saja tanpa } \\
\text { menyadari kewajibannya }\end{array}$ & $\begin{array}{l}\text { menyadari } \\
\text { bahwa } \\
\text { pendidikan } \\
\text { hanyalah salah } \\
\text { satu factor } \\
\text { penyebab } \\
\text { tertinggalnya } \\
\text { kaum } \\
\text { perempuan. } \\
\text { Persoalan } \\
\text { sistemik sosial } \\
\text { budaya } \\
\text { masyarakat } \\
\text { tidak dilihat } \\
\text { dalam halini }\end{array}$ \\
\hline $\mathrm{KB}$ & $\begin{array}{l}\text { Melihat budaya } \\
\text { sebagai sumber } \\
\text { utama } \\
\text { keterbelakangan } \\
\text { perempuan }\end{array}$ & $\begin{array}{l}\text { Perempuan perlu setara } \\
\text { denganlaki-laki } \\
\text { Dalam rumah tercipta relasi yang } \\
\text { seimbang } \\
\text { Dalam politik perempuan harus } \\
\text { ikut berperan }\end{array}$ & $\begin{array}{l}\text { Tidak ada } \\
\text { kesesuaian } \\
\text { antara platform } \\
\text { denganrealitas } \\
\text { sesungguhnya }\end{array}$ \\
\hline KS & $\begin{array}{l}\text { Mengizinkan } \\
\text { perempuan untuk } \\
\text { menempatiposisi } \\
\text { penting } \\
\text { jikadibutuhkan } \\
\text { Membenarkan kader } \\
\text { perempuan } \\
\text { menempati posisi di } \\
\text { parlemen }\end{array}$ & $\begin{array}{l}\text { Kemunduran posisi perempuan } \\
\text { merupakan kesalahan orde baru }\end{array}$ & $\begin{array}{l}\text { Dalam } \\
\text { realitanya, PKS } \\
\text { memisahkan } \\
\text { perempuan } \\
\text { dari pusat } \\
\text { kekuasaan } \\
\text { menjadi } \\
\text { pinggiran }\end{array}$ \\
\hline $\mathrm{AN}$ & $\begin{array}{l}\text { Tidak setujudengan } \\
\text { diskriminasi } \\
\text { gender,dimana } \\
\text { perempuanmasih } \\
\text { sulit memiliki peran } \\
\text { yang sama } \\
\text { antaralaki-laki dan } \\
\text { perempuan }\end{array}$ & $\begin{array}{l}\text { Mengajukan pengambangan } \\
\text { kesempatan bagi perempuan } \\
\text { Melihat perempuan merupakan } \\
\text { lebih separuh dari penduduk } \\
\text { Indonesia } \\
\text { Membentuk departemen } \\
\text { perempuan sebagai sentral } \\
\text { aktifitas partai }\end{array}$ & $\begin{array}{l}\text { Memiliki } \\
\text { pandangan } \\
\text { stereotype } \\
\text { bahwa } \\
\text { perempuan } \\
\text { dapat } \\
\text { memimpin } \\
\text { pada kondisi } \\
\text { tertentu }\end{array}$ \\
\hline
\end{tabular}

Sumber : Jurnal Perempuan, No. $34 ; 41$

Dari penjabaran di atas menunjukkan bahwa keseriusan partai untuk mengakomodir perempuan dalam Partai Politik pada posisi stratgeis masih sangat diragukan. Hal tersebut juga dapat dilihat dari komposisi kepengurusan Partai 
dimana perempuan hanya ditempatkan bukan pada posisi yang terlibat dalam pengambilan keputusan startegis partai.

Sulawesi Selatan khususnya, Partai Politik belum menempatkan perempuan dalam struktur kepengurusan khususnya pada posisi yang dianggap strategis, dan hanya ditempatkan pada posisi yang memiliki korelasi dengan ranah dometik yaki posisi Ketua, Wakil Ketua, Wakil Sekertaris atau Bendahara. Faktanya, kehadiran perempuan di partai politik kadang hanya sebagai pelengkap, atau paling tidak untuk sekedar memenuhi ketentuan yang ada yakni 30\% kepengurusan perempuan.

\section{Tabel 3: Keterwakilan Perempuan dalam Kepengurusan Partai Islam di Sulawesi Selatan}

\begin{tabular}{|c|l|c|c|c|}
\hline o & \multicolumn{1}{|c|}{ Nama Partai } & $\begin{array}{c}\text { Jumlah } \\
\text { Pengurus }\end{array}$ & $\begin{array}{c}\text { Jumlah } \\
\text { Perempuan }\end{array}$ & Persentase \% \\
\hline 1 & $\begin{array}{l}\text { Partai Amanat } \\
\text { Nasional/PAN }\end{array}$ & 105 & 20 & 19,05 \\
\hline 2 & $\begin{array}{l}\text { Partai Keadilan } \\
\text { Sejahtera/PKS }\end{array}$ & 110 & 30 & 27,27 \\
\hline 3 & $\begin{array}{l}\text { Partai Persatuan } \\
\text { Pembangunan }\end{array}$ & 201 & 55 & 27,36 \\
\hline 4 & $\begin{array}{l}\text { Partai Bulan } \\
\text { Bintang/PBB }\end{array}$ & 99 & 32 & 32,32 \\
\hline 5 & $\begin{array}{l}\text { Partai Kebangkitan } \\
\text { Bangsa/PKB }\end{array}$ & 61 & 18 & 29,51 \\
\hline
\end{tabular}

Pada lembaga legislative misalnya di kabupaten Gowa. Dari 45 orang anggota DPRD kabupaten Gowa perempuan berjumlah 13 orang sedangkan laki-laki 32 orang. Legislator perempuan tersebut berasal masing-masing: 5 orang dari Partai Golkar, PDK 3 orang, dan masing-masing 1 (satu) orang dari Partai Demokrat,PKS,PDIP,PBR, dan Gerindra. Dari data tersebut PKS dan Partai Bintang Reformasi (PBR) yang dikategorikan sebagai partai Islam, dimana data tersebut menunjukkan bahwa keberhasilan perempuan untuk duduk dalam lembaga legislative tidak terlepas dari kondisi atau iklim partai politik yang diusungnya.

Kesiapan partai untuk menerima eksistensi perempuan dalam partai masih perlu dikaji lebih dalam. Pandangan tersebut sejalan dengan pendapat Andi Mariattang (legilator PPP, DPRD Propinsi Sulawesi Selatan) bahwa keberhasilan perempuan salah satunya melalui peluang yang diberikan partai politik dan kalangan internal partai, meskipun saat ini peluang tersebut hanya diberikan oleh kelompok perempuan sendiri pada tingkat kepengurusan teratas. Pengurus perempuan pada level yang lebih tinggi sangat berperan merangkul perempuan pada posisi yang kurang strategis (Wawancara, 09 Juli 2012).

\section{Dinamika Relasi Gender dalam Pengambilan Keputusan Strategis Partai}

Ide feminism modern memandang bahwa konstruksi sosial yang telah terbangun dan mempengaruhi cara pandang masyarakat khususnya masyarakat modern yang lebih mengedepankan rasionalitas,universalisme, individualism, dan 
humanisme dengan menempatkan "kata-kata" yang selalu merujuk pada obyek yang ada di dunia nyata. Apa yang terlihat dan menjadi pembicaraan dalam masyarakat diinternalisasi sebagai sesuatu yang yang tidak dapat dibantah. Pandangan terhadap identitas perempuan sebagai" the other" dan menjadi subyek yang berlawanan dengan subyek atau identitas laki-laki. Meskipun laki-laki sebagai subyek yang mendominasi dan memiliki posisi yang vital, tetapi sebuah keniscayaan bahwa subyek tersebut harus memiliki hubungan dengan yang lain (the other), dimana the other selalu diposisikan lebih rendah dan berada di luar kekuasaan.

Pandangan postmodernis memberikan angin segar bagi perluasan peran dan relasi yang lebih luas bagi identitas laki-laki dan identitas perempuan sebagai individu-individu yang menciptakan kebahagiaan bagi dirinya dimana terdapat keleluasaan mencurahkan dirinya terhadap obyek yang dimaknai dapat memberikan kebahagiaan bagi dirinya. Politik merupakan suatu wadah atau suasana mendukung keseimbangan minat dan kebutuhan di satu sisi, namun di sisi lain politik juga menciptakan peluang bagi ambisi pribadi atau pemuasan libido meniti tangga kekuasaan. Sebagaimana diungkapkan Plato bahwa politik adalah seni, seni yang berkaitan dengan pencapaian tujuan serta proses pencapaiannya. Politik adalah "seni kemungkinan" (the art of possibilities), apa yang tidak mungkin bisa menjadi mungkin dalam politik. Dalam berpolitik terdapat kampanye, diplomasi, dan negosiasi, dalam konteks inilah dibutuhkan kekuatan seni untuk meyakinkan. Politik diyakini dapat merubah seseorang dari "nothing" menjadi "something", setelah dikemas menjadi menarik di atas panggung politik.

Relasi sosial (gender) dapat dicermati pada proses pencapaian fungsi partai politik khususnya berkaitan dengan fungsi rekruitmen politik. Fungsi rekruitmen politik mengarah pada penyeleksian kader partai menjadi politisi sebagai ajang kompetensi partai, serta penentuan posisi penting dalam politik lain.

Pada dasarnya, relasi gender dalam khasanah politik kerajaan di Sulawesi Selatan berjalan dengan baik. Salah satunya dari penelitian Rossler $(2000 ; 156)$ yang menunjukkan peran laki-laki dan perempuan yang cukup seimbang. Hal tersebut dibuktikan dari 30 kerajaan di Bone terdapat 7 (tujuh) kerajaan yang dipimpin seorang perempuan. Laki-laki dan perempuan pada posisi dewan adat memiliki peran yang sama dimana perempuan disebut adaq baine (penasehat yang bijak) yang berfungsi sebagai mediator yang antara penduduk desa dengan Dewan Pemerintah Tradisional. Perempuan menjaga dan memelihara benda pusaka (Makassar: kalompoang, Bugis; arajang, Luwu; arajangdan anrosao) yang berfungsi sebagai simbol kekuatan kerajaan.

Keseimbangan relasi dengan berlandaskan prinsip siri' na pacce dikalangan elit politik telah mengalami pergeseran nilai ketika sekulerisme mempengaruhi ranah politik. Untuk meraih dan mempertahankan kekuasaan politik dan ekonomi,elit cenderung memburu efisiensi,nilai guna, dan bersifat transaksional. 